\title{
Spontaneously acquired unilateral macrotia in an adult: Case report
}

\section{Yetişkinde kendiliğinden edinilen tek taraflı makrotia: Olgu sunumu}

\author{
Raşit CEVizCi' ${ }^{1}$, Mehmet DÜZLÜ², Selin ÜSTÜN BEZGiN³, Nebil GÖKSU²
}

\section{ABSTRACT}

Macrotia is one of the rare congenital external ear deformities. This deformity occurs when the measurements of the ear exceeds the standard values. However, enlargement of the ear may occur secondary to other causes and have clinical implications similar to true macrotia. In this report, we present an adult who had previously unilateral, slight auricular asymmetry on his left ear . His left ear enlarged spontaneously within the last four years without genetic, dermatological and rheumatological pathologies. We recommend considering other possibilities in the differential diagnosis and making comprehensive research before surgical intervention to the deformity.

Key words: Macrotia, external ear, deformity öz

Makrotia ender görülen konjenital dış kulak deformitelerinden biridir. Bu deformite dış kulağın standart boyutlarının artması ile oluşur. Ancak dış kulakta başka nedenlerle de büyüme olabilir ve gerçek makrotia gibi klinik olabilir. Bu raporda, daha önce sol kulağında tek taraflı, hafif dış kulak asimetrisi olan, son dört yıl içinde spontane olarak sol kulağı büyüyen, genetik dermatolojik ve romatolojik patolojisi bulunmayan yetişkin hasta sunulmaktadır. Deformiteye cerrahi müdahale öncesi ayırıcı tanıdaki diğer olasılıkların düşünülmesi ve kapsamlı bir araştırma yapılmasını önermekteyiz.

Anahtar kelimeler: Makrotia, dış kulak, deformite

\section{INTRODUCTION}

Macrotia is the enlargement of the external ear. Auricular anthropometric studies determined standards for normal ear measurements in North American Caucasians ${ }^{1}$. Macrotia exists when the size of the ear exceeds these values. In addition, one can talk of an enlarged ear if its length exceeds that of the middle third of the face ${ }^{2}$.

We know that macrotia is a relatively rare congenital external ear deformity ${ }^{3}$. However, occasionally enlargement of external ear may occur secondary to the other causes such as dermatological, rheumatological diseases or trauma ${ }^{4,5}$ and they may give clinical impressions like macrotia.
Reports to date about macrotia have been limited and inaccessible. To best of our knowledge, in this report, we first present an adult who previously had unilateral, slight auricular asymmetry followed by an enlargement of the left ear for four years without genetic, dermatological and rheumatological pathology.

\section{CASE REPORT}

A 52-year old man consulted our outpatient clinic with the complaint of enlargement of the left ear, which was a little bigger than his right ear. The enlargement had occurred spontaneously in the last 5 years without pain or sensitivity other than a minor itching on the left auricle. There was no family history about macrotia or any other congenital or acquired

Received: 05.10 .2015

Accepted: 02.11.2015

${ }^{1}$ Medipol University Faculty of Medicine, Department of Otorhinolaryngology Head and Neck Surgery

${ }^{2}$ Gazi University Faculty of Medicine, Department of Otorhinolaryngology Head and Neck Surgery

${ }^{3}$ Kanuni Sultan Süleyman Education and Research Hospital, Department of Otorhinolaryngology Head and Neck Surgery

Yazışma adresi: Selin Üstün Bezgin, Kanuni Sultan Süleyman Eğitim ve Araştırma Hastanesi, Kulak Burun Boğaz ve Baş Boyun Cerrahisi Bölümü, İstanbul

e-mail: drselinustun@gmail.com 
developmental abnormality or any other systemic disease. He was an active smoker who used 2 packs a day for 14 years. Otorhinolaryngological physical examination revealed only unilateral macrotia on his left ear (Figure 1). The appearance of the auricular skin was normal.

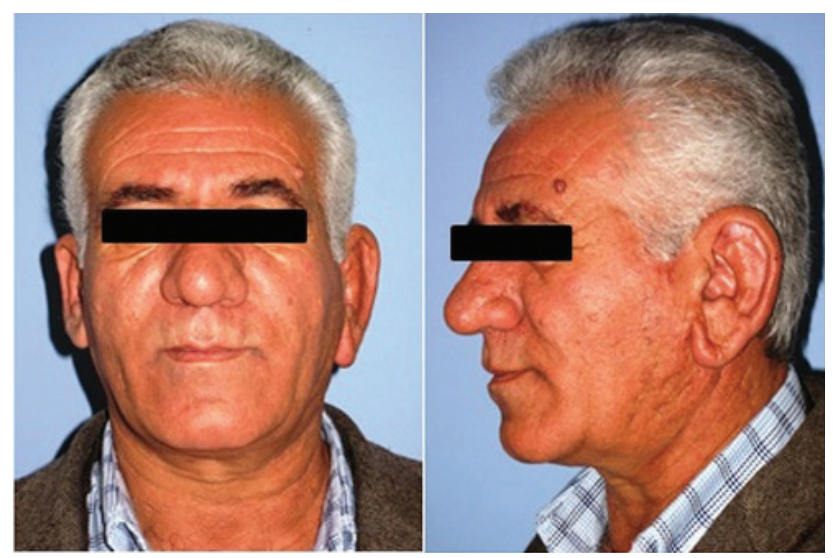

Figure 1. Left unilateral macrotia.

His audiological, and radiological examination of the temporal region with magnetic resonance (MRI) and computed tomography (CT) was within normal limits. He was consulted to rheumatology department in order to exclude the other possible pathologies like systemic inflammatory or immunologic diseases. When systemic evaluation was performed, he complained about joint pains, extreme sweating, mouth and eye dryness. Rheumatologists performed systemic examination and then multiple analysis including complete blood count $(C B C)$, routine biochemistry, urinalysis, vitamin B12, folic acid, ferritin, thyroid functions, sedimentation, rheumatoid factor (RF), C-reactive protein (CRP), antinuclear antibody (ANA), epithelial cell-derived neutrophil-activating peptide (ENA) profile whose results were all within normal limits. Pulmonary and pelvic radiograms were performed to detect the presence of sarcoidosisamyloidosis and sacroileitis, respectively, and then abdomen and neck ultrasonograms were obtained in order to find if any other additional organomegaly existed. Consequently, the imaging results were within normal limits. He was than consulted to dermatology department to inquire about the multiple papules on his neck region. The department thought the lesions on the neck region were skin tags but they recommended auricular biopsy in order to exclude granulomatous diseases and material retention. Auricular skin biopsy result was compatible with actinic keratosis and solar elastosis, and there was no amyloid retention on crystal violet staining.

After excluding all possible systemic and local diseases, we referred the patient to plastic and reconstructive surgery department for autoplastic surgery. Full-thickness V-shaped segment resection technique was used for correction of the deformity. The final histopathology result of the excluded auricular specimen was sebaceous gland hyperplasia. Three months later after surgery the patient was troublefree with no evidence of systemic or local problem including flap necrosis.

\section{DISCUSSION}

Macrotia is a relatively rare deformity of the external ear, which occurs when the auricular dimensions exceeds the standard values ${ }^{2}$. Therefore, knowledge of normal ear dimensions is useful in the diagnosis of deformities of the external ear. Previously, Farkas et al. ${ }^{1}$ reported the most comprehensive study about measurements and general morphology of the auricle and established the auricular growth of normal West German and North American Caucasian population. Subsequently, few studies on this aspect have been undertaken in several ethnic groups ${ }^{6-13}$.

Farkas et al. ${ }^{6}$ observed that ear width reaches mature sizes in males at 7 years and in females 6 years of age, and ear length in males at ${ }^{13}$ years and in females at 12 years of age. However, significant variations are seen in the sizes and the maturation ages between the populations $s^{7,9,10,12}$.

We know that the size of human auricle continues to increase even after completion of development and reaching adulthood ${ }^{14,15}$. Length and width increments of the auricle during various stages of life and differences between the sexes were estimated in several studies ${ }^{9,10,15,16}$. The explanations for this phe- 
nomenon were diverse. Iannerelli ${ }^{17}$ observed that an increase in auricle length with age was largely due to sagging of the cartilage-free earlobe. However, Ito et al. ${ }^{15}$ elucidated the mechanism of continuous expansion of the auricle after adulthood by using light and electron microscopy to examine the adult human auricular cartilage. The authors observed elastic fibers with relatively homogenous thickness in the young group whereas in the aged group elastic fibers were heterogeneous in thickness. In addition, they found the number of chondrocytes per unit area in the aged group was significiantly less than in the young group. It was hypothesized that the auricle expansion may be explained by expansion of the extracellular matrix of the cartilage $\mathrm{e}^{15}$.

In our patient, we observed total expansion of the left auricle involving length, width and ear lobe. Height, rather than the width of the ear increased. We noticed that earlobe lengthening contributed mainly to the increase in auricular length. Consequently, we cannot explain the expansion of auricle in our patient with the hypothesis of Ito et al. for why expansion during adulthood occurs at a slower pace and bilaterally. Whereas in our patient unilateral, and spontaneous enlargement of the auricle developed.

Macrotia usually exists as a congenital ear deformity ${ }^{3}$. It may also appear in syndromes ${ }^{18}$. Occasionally, it may be acquired secondary to the other causes such as dermatological, rheumatological diseases or trauma. In the literature, there is a report that presented a patient with subaural arteriovenous malformation complicated by macrotia 4 . Further, some rheumatological diseases such as sarcoidosis and amyloidosis should be included in the differential diagnosis of acquired external ear deformities because of their various manifestations, which may involve the external ear ${ }^{5,19}$.

In our case, although there was no clue of any other disease in order to make certain of the absence of any other systemic abnormality, we performed all systemic examination of patient, blood analysis, required imaging techniques and auricular skin biopsy.
In addition, we investigated temporal region by computed tomography and magnetic resonance as for the presence of a local pathology, which may cause auricle expansion. As a result, we obtained no systemic disease-associated data and decided that ear reduction was an appropriate treatment. Eventually, we referred the patient to plastic and reconstructive surgery department. They used ear reduction technique that consists of full thickness V-shaped segment resection from upper pole of the ear and earlobe for the correction of macrotia.

\section{CONCLUSION}

Macrotia is a rare deformity, involving the enlargement of external ear. Although macrotia is usually congenital, it may manifest spontaneously during adulthood. The authors recommend detailed examination for the possible underlying causes before surgical intervention for the correction of macrotia.

\section{REFERENCES}

1. Farkas LG. Anthropometry of normal and anomalous ears. Clin Plast Surg 1978;5:401-12.

2. Yuen A, Coombs CJ. Reduction otoplasty: Correction of the large or asymmetric. Ear Aesth Plast Surg 2006;30:675-8. http://dx.doi.org/10.1007/s00266-006-0119-3

3. Tuncer S, Demir Y, Atabay K. A simple surgical technique for correction of macrotia with poorly defined helical fold. Aesth Plast Surg 2000;34:136-49. http://dx.doi.org/10.1007/s00266-008-9268-x

4. Yoshida Y, Ishizawa T, Mitsuhashi Y, et al. A patient with subaural arteriovenosus malformationcomplicated by macrotia. Clin Exp Dermat 2005;31:129-56.

5. Adelola AO, Fernandez R, Ahmad R, et al. Sarcoidosis of the external ear - literature review and report of a case. J Laryngol Otol 2006;121:289-92.

6. Farkas LG, Posnick JC, Hreczko TM. Anthropometric growth study of the ear. Cleft Palate Craniofac J 1992;29:324-9. http://dx.doi.org/10.1597/1545-1569(1992)029<0324:AGS OTE >2.3.CO;2

7. Kalcioglu MT, Miman MC, Toplu Y, et al. Anthropometric growth study of normal human auricle. Int J Pediat Otorhinolaryngol 2003;67:1169-77. http://dx.doi.org/10.1016/S0165-5876(03)00221-0

8. Bozkir MG, Karakas P, Yavuz M, Dere F. Morphometry of the external ear in our adult population. Aesth Plast Surg 2006;30:81-5. http://dx.doi.org/10.1007/s00266-005-6095-1

9. Gualdi-Russo E. Longitudinal study of anthropometric changes with ageing in an urban Italian population. Homo 1998;49:241-59.

10. Ferrario VF, Sforza C, Ciusa V, et al. Morphometry of normal 
human ear: A crosssectional study from adolescence to midadulthood. J Craniofac Genet Dev Biol 1999;19:226-33.

11. Brucker MJ, Patel J, Sullivan PK. A morphometric study of the external ear: Age and sex-related differences. Plast Reconstr Surg 2003;112:647-52.

http://dx.doi.org/10.1097/01.PRS.0000070979.20679.1F

12. Purkait R, Singh P. Anthropometry of normal human auricle: a study of adult Indian men. Aesth Plast Surg 2007;31:372-9. http://dx.doi.org/10.1007/s00266-006-0231-4

13. Azaria R, Adler N, Silfen R, et al. Morphometry of the adult human earlobe: A study of 547 subjects and clinical application. Plast Reconstr Surg 2003;111:2398-402. http://dx.doi.org/10.1097/01.PRS.0000060995.99380.DE

14. Heathcote JA. Why do old men have big ears? BMJ 1995;311:1668.

http://dx.doi.org/10.1136/bmj.311.7021.1668
15. Ito I, Imada M, Ikeda M, et al. A morphological study of age changes in adult human cartilage with special emphasis on elastic fibers. Laryngoscope 2001;111:881-6. http://dx.doi.org/10.1097/00005537-200105000-00023

16. Meijermann L, Lugt C, Maat GJR. Cross-sectional anthropometric study of the external ear. J Forensic Sci 2007;52:286-92. http://dx.doi.org/10.1111/j.1556-4029.2006.00376.x

17. Iannarrelli AV. Ear identification forensic identification series. Fremont, CA: Paramount Publishing Company, 1989.

18. Verloes A, Lesenfants S, Phillipet B, et al. Microcephaly, macrotia, unusual mimics and mental retardation syndrome: new syndrome or variant of De Lange type 2 syndrome. Genet Couns 1996;7:277-82.

19. Wenson SF, Jessup CJ, Johnson MM, et al. Primary cutaneous amyloidosis of the external ear: a clinicopathological and immunohistochemical study of 17 cases. J Cutan Pathol 2012;39:263-9.

http://dx.doi.org/10.1111/j.1600-0560.2011.01812.x 